\title{
Recenzja
}

\section{„Reality of Politics. Estimates, comments, forecasts”, No. 1, 2010 Czasopismo Instytutu Politologii i Europeistyki Uniwersytetu Szczecińskiego, ss. 271}

W listopadzie 2010 roku ukazał się pierwszy numer nowego czasopisma naukowego „Reality of Politics. Estimates, comments, forecasts”. Wydawcą tego rocznika jest Wydawnictwo Adam Marszałek z Torunia, od wielu lat specjalizujące się w tematyce bezpieczeństwa międzynarodowego. Redaktorem naczelnym jest prof. dr hab. Jarosław J. Piątek. Funkcję zastępcy redaktora pełni dr Renata Podgorzańska, natomiast sekretarzami zostali: mgr Justyna Brylewska i mgr Tomasz Czapiewski. Pozostałymi członkami Komitetu redakcyjnego są pracownicy naukowi z wielu ośrodków uniwersyteckich (T. Bodio, E. Cała-Wacinkiewicz, M. Chmaj, Ch. Elworthy, K. Fiedor, K. Janik, B. Koszel (przewodniczący), M. Kowalewski, J. Marszałek-Kawa, E. Olszewski, J. Ruszkowski, A. Wojtaszak, K. Pałecki, S. Wojciechowski, A. Żukowski), co daje gwarancję, że czasopismo jest merytorycznie i technicznie na wysokim poziomie.

„Reality of Politics”, zgodnie z głównym założeniem Komitetu redakcyjnego, ma stanowić naukowe forum wymiany poglądów i opinii naukowców, dotyczących badań nad bezpieczeństwem europejskim i światowym, jak również przedstawia szerokie spectrum opinii, poglądów oraz refleksji z zakresu współczesnych zagadnień politologicznych. W ostatnich latach znacznie wzrosło zainteresowanie zagadnieniami NATO i bezpieczeństwa Unii Europejskiej. Na polskim rynku wydawniczym pojawiło się wiele czasopism o podobnej tematyce, lecz „Reality of Politics” jako pierwszy porusza tematykę bezpieczeństwa światowego w sposób nowatorski, co zasługuje na aprobatę.

Zadaniem Komitetu redakcyjnego jest próba poszerzenia kręgu czytelników i autorów z wielu środowisk uniwersyteckich polskich i europejskich. Służyć temu ma anglojęzyczna formuła czasopisma i szeroki wachlarz form publikowanych na łamach czasopisma. W pierwszym numerze czasopisma 
zamieszczone zostały artykuły o tematyce politologicznej, skupiającej się przede wszystkim na problemie bezpieczeństwa światowego.

Warto zaznaczyć, że wszystkie publikowane artykuły napisane są w języku angielskim i tylko teksty w tym języku są przyjmowane przez Komitet redakcyjny. Zabieg ten ma na celu dotarcie do największej liczby czytelników i publikujących. Spis treści czasopisma posiada wersję niemieckojęzyczną, co dodatkowo podkreśla tę ideę. W części wstępnej czytelnicy i przyszli autorzy mogą znaleźć informacje dotyczące tematyki kolejnego numeru czasopisma. Ogółem wszystkim opublikowanych artykułów jest szesnaście i dwie recenzje. Jeden z artykułów jest w wersji niemieckojęzycznej. Kryterium kolejności publikowania artykułów odnosi się do kolejności alfabetycznej nazwisk autorów. Klucz ten umożliwił lepsze zarządzanie układem publikacji.

Połowa artykułów dotyczy tematyki bezpieczeństwa europejskiego i światowego w kontekście działań NATO. Do tej części czasopisma możemy zaliczyć opracowania dotyczące znaczenia NATO dla bezpieczeństwa europejskiego (M. Franz), systemu antykryzysowego NATO (K. Kościelniak), znaczenia NATO w nowym świecie (K. Kubiak), kwestii bezpieczeństwa globalnego systemu politycznego (C. Monteleone), czarnego scenariusza dla NATO z lat zimnej wojny (J. J. Piątek), polskiego zaangażowania się w interwencję na Bałkanach w kontekście stanowiska NATO (R. Podgórzańska) oraz francuskiego powrotu do struktur NATO (J. v. Wedel). Podsumowaniem tej tematyki jest artykuł przedstawiający wnioski płynące $\mathrm{z}$ analizy stosunków Europy i NATO wczoraj, dziś i w przyszłości (R. Willa).

Pozostała część artykułów opiera się o problematykę bezpieczeństwa narodowego i europejskiego. Kolejne opracowania przedstawiają porządek światowy po zimnej wojnie (Ł. Dunaj), rozłam w międzynarodowych stosunkach politycznych ze względu na interwencję państw europejskich w Iraku (Ł. Jureńczyk), misje ISAF w Afganistanie w kontekście nowej strategii bezpieczeństwa USA (B. Kruszyński \& E. A. Parthemore), politykę światową w 1990 roku (P. Krzyżański), międzynarodowe bezpieczeństwo z perspektywy USA i Rosji (D. Mierzejewski), ponadnarodową koncepcję dla Unii Europejskiej w zglobalizowanym świecie (J. Ruszkowski), a także geopolityczne i prakseologiczne aspekty stosunków międzynarodowych (B. Z. Szałek) oraz bezpieczeństwo międzynarodowe po upadku układu bipolarnego na świecie (A. Żukowski). 
W czasopiśmie udało się przedstawić różnorodność podejść do kwestii bezpieczeństwa międzynarodowego i funkcjonowania struktur NATO. Szerokie i zróżnicowane dobranie artykułów uważamy za przemyślany zabieg Komitetu redakcyjnego.

Całość pierwszego numeru „Reality of Politics” dopełniają dwie recenzje opracowań wydanych w 2009 r. staraniem Wydawnictwa Adam Marszałek. Pierwsza z nich to: From Zborowo to Nato 1649-2009, a druga to: Polish soldiers on foreign missions and peace operations in the years 1953-1989.

Informacje dotyczące czasopisma „Reality of Politics” można odnaleźć na stronie internetowej Instytutu Politologii i Europeistyki Uniwersytetu Szczecińskiego w zakładce poświęconej pismom naukowym.

Tak więc z wymienionych powyżej powodów uważamy, iż należy uznać ideę publikowania tego typu czasopisma za niezwykle cenne przedsięwzięcie naukowe, które zdecydowanie należy kontynuować i rozwijać.

Sabina Grabowska (Uniwersytet Rzeszowski)

Katarzyna Zielińska (Uniwersytet Pedagogiczny im. KEN w Krakowie) 